\title{
Evaluation of Relationships Between Weather Patterns and Prevalence of Sorghum Ergot in the Texas Panhandle
}

\author{
F. Workneh and C. M. Rush
}

Texas Agricultural Experiment Station, Bushland 79012.

Accepted for publication 7 March 2002.

\section{ABSTRACT}

Workneh, F., and Rush, C. M. 2002. Evaluation of relationships between weather patterns and prevalence of sorghum ergot in the Texas Panhandle. Phytopathology 92:659-666.

Sorghum ergot caused by Claviceps africana was observed for the first time in the United States in Southern Texas in 1997. That year there was a widespread ergot epidemic in hybrid seed production fields in the Texas Panhandle. However, occurrence of the disease has been sparse during the past 3 years, easing fears that the hybrid seed industry in the region might be endangered. To determine whether climatic factors were associated with observed variations in prevalence of ergot, weather data (temperature, precipitation, and relative humidity) were collected from seven weather stations in the Texas Panhandle. Sorghum ergot prevalence data for the period 1997 to 2000 were collected from records of seed companies in the Panhandle and related to weather variables. Results showed that, in the southern section of the Panhandle, maximum temperature and precipitation between 1 and 15 August were associated $\left(r^{2}=\right.$ $0.98, P=0.001$ and $r^{2}=0.81, P=0.0193$, respectively) with variations in the prevalence of ergot during the 4-year period. In the northern section, only maximum temperature during 16 to 31 July was significantly associated $\left(r^{2}=0.91, P=0.0111\right)$ with disease prevalence. Over all, 1997 was wetter and cooler, during the 1 to 15 August period, than each of the subsequent 3 years. In addition to creating humid conditions for ergot development, precipitation was associated with suppression of maximum temperature, enhancing ergot-favorable temperature conditions. Examination of historic weather data for the region showed that there were many instances in the past where temperature depression was associated with a rise in cumulative precipitation, creating ergot-favorable conditions similar to those in 1997. Cross-spectral analysis was used to determine whether such association is periodic. Weather data from five of the seven locations in the region showed peaks of significant coherency $(\alpha<$ 0.05 ) at 2 to 4 years and 7 to 10 years or greater, indicating the existence of a periodic cycle in the temperature-precipitation association. The results of the investigation suggested that association of precipitation with temperature depression is a primary factor in development of ergot in the Texas Panhandle, and such association has a periodic cycle.

Additional keywords: honeydew, time series.
Each year, approximately 3.6 million ha of grain sorghum (Sorghum bicolor (L.) Moench) are grown in the United States, with an annual value of close to $\$ 1$ billion (2). Texas ranks second in grain production following Kansas, but produces 85 to $95 \%$ of all hybrid sorghum seed planted in the United States. Historically, the majority of hybrid seed has been produced in the Texas Panhandle because of the absence of major pest problems, primarily attributed to the hot, dry weather conditions. However, the arrival of sorghum ergot in the United States caused serious concerns about the future of the hybrid sorghum seed industry in the country.

Sorghum ergot, caused by Claviceps africana Frederickson, Mantle, and de Milliano or C. sorghi Kulkarni, Seshadri, and Hedge, is a destructive disease of sorghum that affects unfertilized flowers (19). The disease has been a chronic production problem in sorghum-growing regions of Africa and Asia for many years $(4,20)$. The American continent was free of ergot until it was first discovered in Brazil in 1995 (35). The disease subsequently spread across much of the sorghum-producing regions of South America and Central America, causing severe epidemic $(3,38)$. In the United Sates, sorghum ergot caused by $C$. africana was reported for the first time in 1997 in South Texas and spread the same season across the country, as far north as Nebraska and eastward to Georgia $(4,21)$.

Ergot is strictly a disease of unfertilized ovaries. Once a flower becomes pollinated, it is effectively immune to infection. The dis-

Corresponding author: C. M. Rush; E-mail address: cm-rush@tamu.edu

Publication no. P-2002-0422-01R

(c) 2002 The American Phytopathological Society ease, therefore, is more problematic in male sterile, hybrid-seed production fields than in self-fertilized commercial grain fields. Ovaries from infected flowers become filled with fungal mycelium (sphacelia) that produce copious amounts of honeydew (15). In addition to direct yield loss, sorghum ergot causes a multitude of production problems. Honeydew, produced by sphacelia, runs down stems and leaves and, when disease becomes widespread within a field, the honeydew gums up machinery, impeding grain harvest and bailing of forage sorghum. Honeydew-coated seeds frequently become infested with saprophytes (20), resulting in poor grain quality. Seed germination is reduced and seedlings from honeydew-infested seed exhibit slow growth and poor vigor (27). There is also some indication that feed consumption, by animals fed with infested grain, is reduced $(4,11)$.

In 1997, seed companies in the Texas Panhandle spent millions of dollars in trying to control sorghum ergot using various methods. Despite the efforts, ergot caused widespread damage to hybrid seed production fields across the Panhandle and appeared to pose a major constraint to hybrid seed production in the region. However, during the last 3 years, the prevalence of ergot in the region has been sparse and the threat to hybrid seed production seemingly has subsided. The cause of the sudden explosion of sorghum ergot during the first year of its appearance in 1997 and its decline during subsequent years is uncertain. It has been speculated that growers may have adopted better pollen management strategies, or weather conditions for the development of the disease may not have been as favorable as in 1997.

The sorghum ergot pathogen is reported to require near $100 \%$ relative humidity for $24 \mathrm{~h}$ at $19.5^{\circ} \mathrm{C}$ for optimum infection (20, $30)$. It also has been reported that disease development is negligible above 28 to $30^{\circ} \mathrm{C}$ (30). Windborne spores infect unfertilized 
ovaries through the stigma (15-17) and the ovaries become resistant after fertilization (19). Hence, any management or environmental factor that interferes with fertilization of the ovaries increases the risk of infection (19). For example, lack of synchrony between male and female flowers in hybrid seed production fields may leave the ovaries open to infection. Prolonged wet condition during anthesis may render pollen ineffective. Also, pre-flowering cold stress affects viability of pollen $(8,12)$, reducing pollination efficiency that may lead to infection by the pathogen $(28,31)$.

In the Texas Panhandle, during the summer months, particularly in July and August, high daytime maximum temperature (normally 32 to $33^{\circ} \mathrm{C}$ and occasionally surpassing $38^{\circ} \mathrm{C}$ ) accompanied by low relative humidity is the general rule. Plant diseases that thrive in low to moderate temperatures and high relative humidity normally are seldom encountered. In view of the predominantly hot, dry climate in the Texas Panhandle, the widespread ergot epidemic of 1997 was unexpected. Either the weather pattern in 1997 was anomalously conducive to the ergot epidemic, or the biology of the ergot pathogen and the epidemiology of the disease need to be reevaluated.

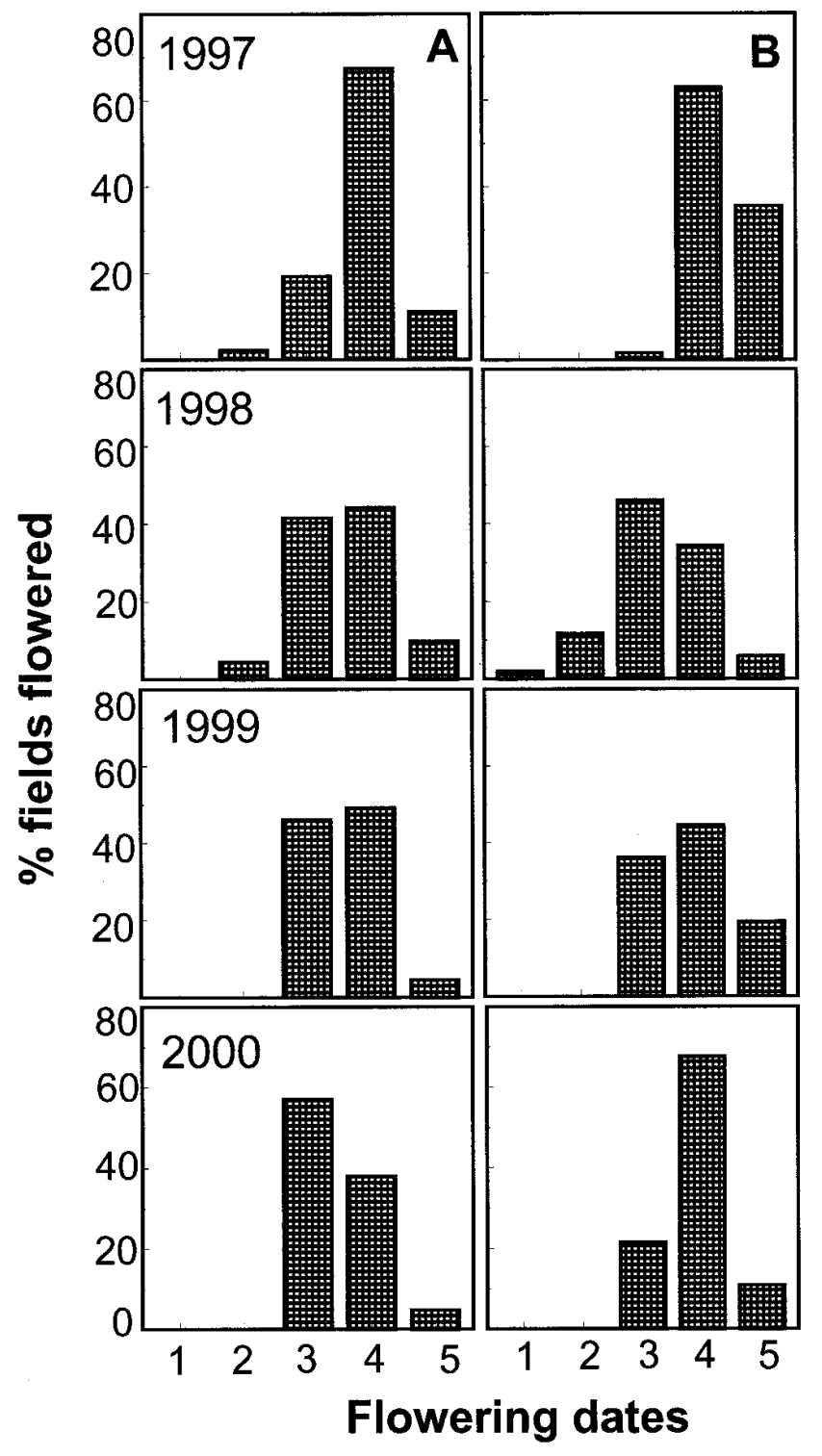

Fig. 1. Flowering dates and the percentage of fields flowered in the $\mathbf{A}$, northern and $\mathbf{B}$, southern sections of the Texas Panhandle during 16 June to 31 August for the fields from which ergot prevalence data were collected between 1997 and 2000. Flowering date $1=16$ to 30 June, $2=1$ to 15 July, $3=$ 16 to 31 July, $4=1$ to 15 August, and $5=16$ to 31 August.
The sparsity of the disease in hybrid sorghum production fields during the last 3 years has led some to believe that ergot is no longer a major threat but a mere nuisance. However, the consistent yearly reports of its occurrence in the region, regardless of how sporadic they may be, suggest that the pathogen is established and may be becoming endemic in the region. Therefore, given the right conditions, an ergot epidemic similar to that in 1997 could develop anytime in the future. If the weather conditions in 1997 were indeed unusually conducive, it would be of interest to hybrid sorghum producers in the region to know how often such weather conditions had occurred in the past, and the prospects of their recurrence in the future. In addition, identification of factors associated with variations in prevalence of the disease is important for making better management decisions. The primary objectives of this project were to (i) describe the 1997 weather conditions and compare with subsequent years in order to determine the relationships between weather factors and the prevalence of sorghum ergot in the Texas Panhandle during the past 4 years, and (ii) investigate whether there are periodicities in the Panhandle climatic pattern which may be conducive to ergot development.

\section{MATERIALS AND METHODS}

The majority of hybrid sorghum seed production in the Texas Panhandle is located in an area that stretches from Lamesa to Dalhart, approximately $32.72^{\circ} \mathrm{N}$ to $36.08^{\circ} \mathrm{N}$. The northern onefourth of the production area is separated from the rest by an approximately $80-\mathrm{km}$ stretch of rangeland drained by the Canadian River. This northern section is generally cooler and also higher in altitude than the larger southern section. We, therefore, treated the hybrid sorghum seed production area in the Panhandle

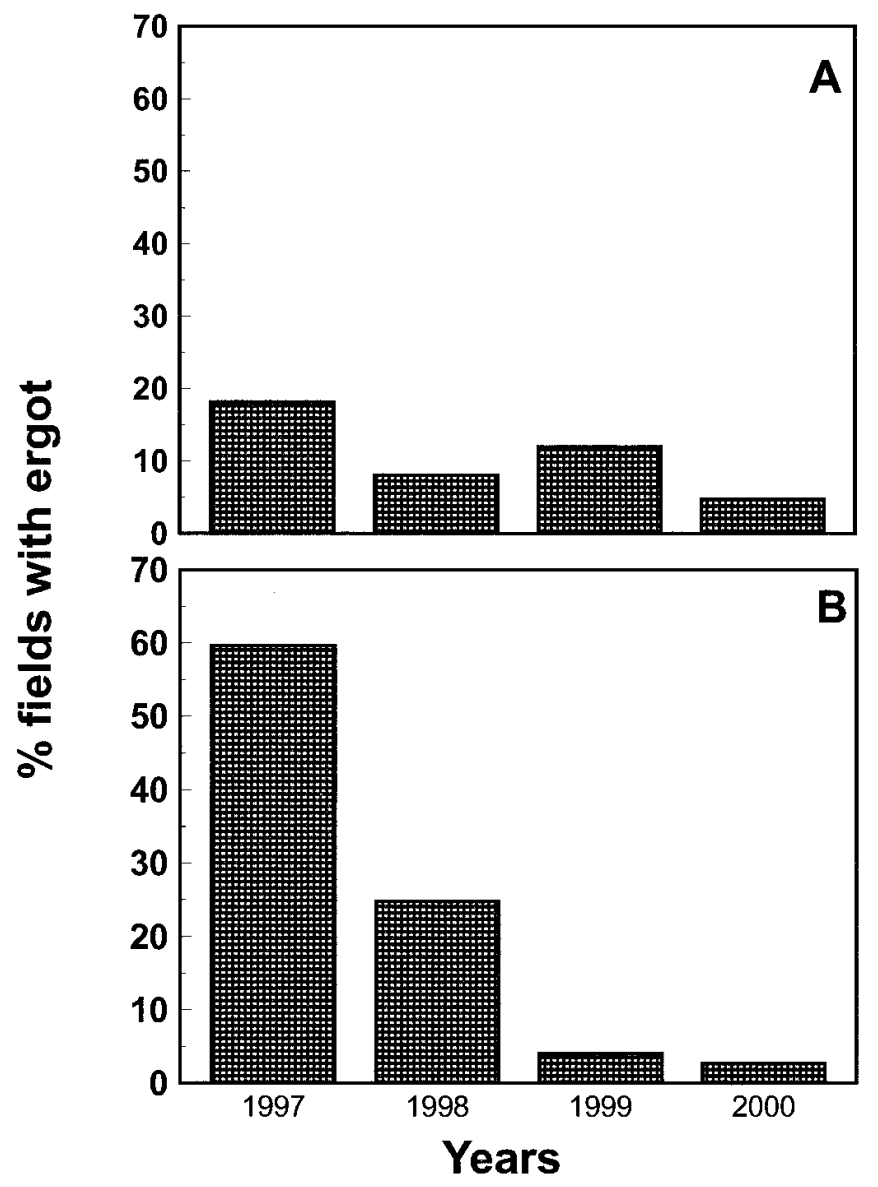

Fig. 2. Percentage of fields with ergot from 1997 to $2000(n=655)$ in the $\mathbf{A}$, northern and $\mathbf{B}$, southern sections of the Texas Panhandle. 
as two distinct sections-north and south. Our classification method, in large part, coincided with the district classification system (Northern and Southern High Plains) of the Texas Agricultural Statistics Service.

Collection of ergot prevalence data. Seed companies usually maintain records of agronomic practices for individual seed production fields, including flowering dates and disease data. Many of the seed companies in the Texas Panhandle have kept records of ergot data since 1997. Ergot and flowering date for the period between 1997 and 2000 for 655 fields across the Panhandle were collected from records of seed companies in the Panhandle. The ergot data consisted of evaluations of individual fields in terms of whether ergot was present or absent during each year of the 4-year period.

Collection of weather data. Temperature and precipitation data for the last 50 years were collected from the National Climatic Data Center (NCDC, Ashville, NC) for two weather stations (Dalhart and Dumas) representing the northern section and for five weather stations (Crosbyton, Hereford, Lamesa, Lubbock, and Plainview) representing the southern section. Relative humidity data for the last 4 years were collected from the Northern Plains (Etter) and Southern Plains (Dimmitt, Halfway, and Lamesa) potential evapotranspiration (PET) network stations. All weather stations are located between latitudes of $32.72^{\circ} \mathrm{N}$ (Lamesa) and $36.08^{\circ} \mathrm{N}$ (Dalhart) and longitudes of $101.3^{\circ} \mathrm{W}$ (Crosbyton) and $102.5^{\circ} \mathrm{W}$ (Dalhart), with a south-to-north altitude ranging from $988 \mathrm{~m}$ (Lamesa) to $1,223 \mathrm{~m}$ (Dalhart). These weather stations were selected based on distribution of fields from which ergot prevalence data were collected and completeness of the data for each weather variable for the specified time period.

Data analyses. The favorable temperature range for sorghum ergot development is reported to be between 14 and $28^{\circ} \mathrm{C}$, with a maximum limit of $30^{\circ} \mathrm{C}(4,30)$. McLaren and Wehner (30) and McLaren and Flett (29) reported that mean daily maximum temperature during anthesis was one of the weather variables that strongly influenced sorghum ergot severity. In our study, $30^{\circ} \mathrm{C}$ (daily maximum temperature) was used as a baseline for the upper limit for ergot development. Cumulative departure of daily maximum temperature from $30^{\circ} \mathrm{C}$ then was used to compare the years (1997 to 2000) in terms of ergot prevalence. In the Texas Panhandle, most sorghum flowering dates lie between 15 July and 15 August, and flowering dates for most the fields from which the ergot data were collected fell within the general range (Fig. 1A and $\mathrm{B})$.

C. africana infects only unfertilized flowers; therefore, infection periods can be estimated once flowering dates are known.

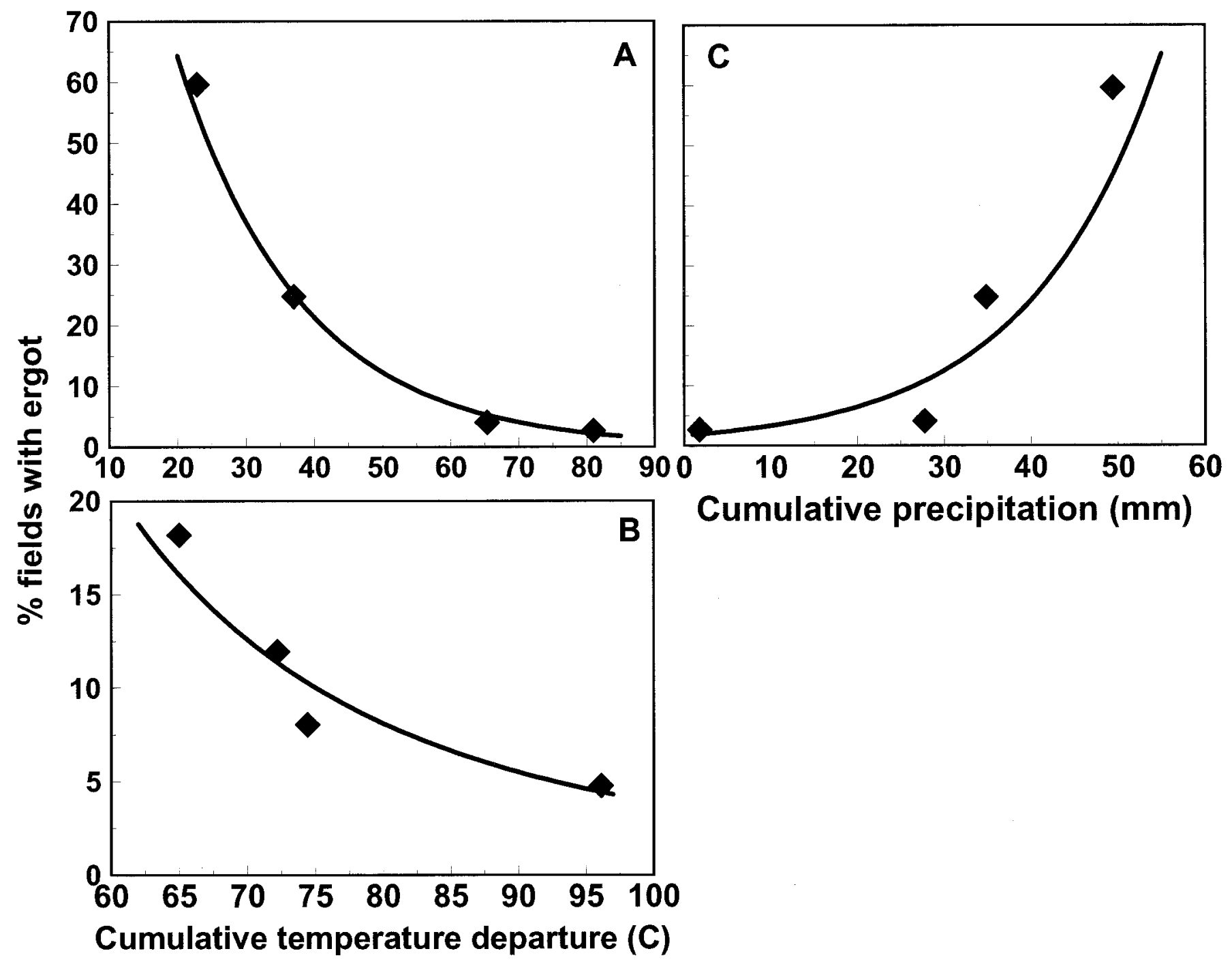

Fig. 3. A, Relationships between cumulative maximum temperature departure from $30^{\circ} \mathrm{C}\left(R^{2}=0.98, P=0.001, Y=193.97 \times \exp (-0.055 X)\right.$; B, cumulative precipitation $\left(R^{2}=0.81, P=0.0193, Y=1.72 \times \exp (0.066 X)\right.$ and the percentage of fields with ergot in the southern section of the Panhandle during 1 to 15 August; $\mathbf{C}$, relationship between cumulative maximum temperature departure $\left(R^{2}=0.91, P=0.0111, Y=1.4 \times 10^{7} X^{-3.29}\right)$ and the percentage of fields with ergot during 16 to 31 July in the northern section of the Panhandle from 1997 to 2000. Each data point represents the mean of two and five stations in the northern and southern sections, respectively. 
However, a given field may continue to flower for up to 3 to 4 weeks, making it difficult to pinpoint time of infection. Therefore, blocks of periods between 1 July and 31 August were compared for estimation. Regression analysis then was used to relate cumulative temperature departure (means of weather stations) in each section of the Panhandle for various durations between 1 July and 31 August to the percentage of fields with ergot. For example, cumulative departures between 1 and 5 July or between 1 and $10 \mathrm{July}$, and so on, were regressed against ergot prevalence over the 4-year period to determine which period most distinguished between years in terms of disease prevalence. Cumulative precipitation and average relative humidity during the various periods between 1 July and 31 August were similarly regressed against the percentage of fields with ergot.

Cross-spectral analysis. To determine whether there are periodicities in ergot-conducive weather patterns, cumulative departures of daily maximum temperatures from $30^{\circ} \mathrm{C}$ and cumulative precipitation were calculated for weather data from 1950 to 2000 for the seven weather stations. The calculated temperature and precipitation data were transformed using the Box-Cox transformation procedure (7). Cross-spectral analysis (a branch of time series analysis) was conducted on the transformed data to assess the coherence (a measure of association) of the two time series. The raw spectrum of the series was filtered using a triangularly weighted function with 7 bandwidth. Filtering is a smoothing technique designed to reduce local noises $(10,25)$. Most time series analyses, including cross-spectral analysis, require that the series be stationary (its properties not changing with time) $(9,22)$. Visual inspection of the autocorrelation function for each series showed a slow decay in relation to lag increments indicating that both temperature and precipitation series have non-stationary variances (23). The nonstationarity problem was alleviated by differencing (first order) the series (9). Before any analysis was conducted, both precipitation and temperature series were tested for white noise (a sequence of uncorrelated random variables with zero mean and finite variance) (37), using Bartlett's KolmogorovSmirnov Statistic $(5,13,18,33)$. All statistical analyses were conducted with the use of SAS software (SAS Institute Inc., Cary, $\mathrm{NC)}$.

\section{RESULTS}

Ergot prevalence and weather factors. In 1997, sorghum ergot was observed in 59.7 and $18.2 \%$ of seed production fields in the southern and northern sections, respectively, of the Texas Panhandle (Fig. 2A and B). Both sections had the greatest prevalence of ergot in 1997, and prevalence of disease declined over the subsequent 3 years and was the least in 2000 .

In the southern section, prevalence of ergot during the 4-year period strongly correlated with cumulative departure of daily maximum temperature from $30^{\circ} \mathrm{C}$ during 1 to 15 August $\left(r^{2}=\right.$ $0.98, P=0.001$ ) (Fig. 3A). The prevalence of disease declined exponentially as cumulative departures from $30^{\circ} \mathrm{C}$ positively increased. In the northern section of the Panhandle, there was no significant relationship between cumulative departure in maximum temperature and the prevalence of ergot during 1 to 15 August. However, there was a strong relationship between cumulative maximum temperature departure and the prevalence of ergot during 16 to 31 July ( $\left.r^{2}=0.91, P=0.0111\right)$ (Fig. 3B).

In the southern section, cumulative precipitation during 1 to 15 August related less strongly to the prevalence of the disease than cumulative temperature departure $\left(r^{2}=0.81, P=0.0193\right)$ (Fig. $3 C)$. The percentage of fields with ergot increased exponentially with increase in cumulative precipitation during 1 to 15 August. In 1997, during the 15-day period, there was $49.5 \mathrm{~mm}$ of rain compared with $1.8 \mathrm{~mm}$ in 2000 (mean of five stations). In the northern section, the trend in precipitation during the 4-year period was similar to that of the southern section (data not shown). However,

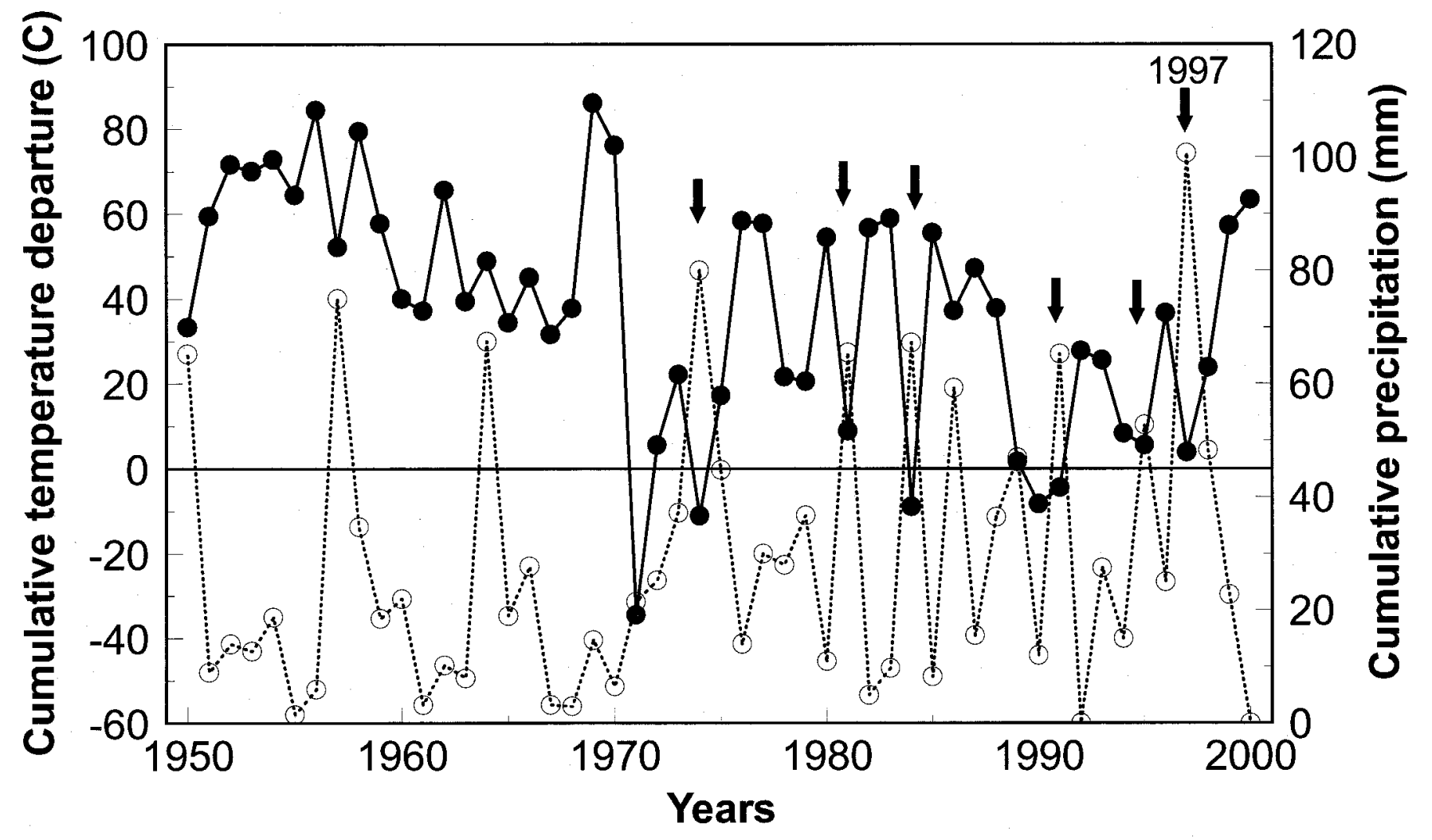

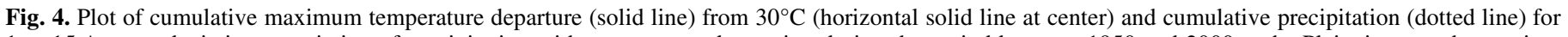

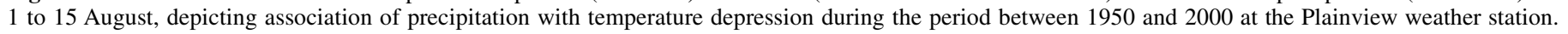
Arrows point to periods in which such association occurred. 
the relationship between precipitation and the prevalence of ergot was not significant in any of the periods between 1 July and 31 August.

Means of average relative humidity for the four PET stations in the region related to the prevalence of ergot similar to precipitation, and there was a strong relationship between average relative humidity and precipitation $\left(r^{2}=0.99, P<0.0001\right.$; data not shown) indicating that high relative humidity was almost exclusively associated with precipitation.

In both north and south sections of the Panhandle, plots of cumulative departures of daily maximum temperatures from $30^{\circ} \mathrm{C}$ and cumulative precipitation for the various weather stations during the last 50 years showed that there was a negative relationship between the two. For example, at the Plainview station, in many instances during the 50-year period, an increase in cumulative precipitation was accompanied by a depression in cumulative maximum temperature departure to a level near or below $30^{\circ} \mathrm{C}$ (Fig. 4), indicating that precipitation was associated with achievement of ergot-favorable temperature range. However, the degree of relationship between precipitation and temperature depression depended on latitudinal locations. The correlation coefficients of the relationships for six of the seven stations ranged from -0.33 $(P=0.0236)$ at the northern Panhandle (Dumas station, $\left.35.87^{\circ} \mathrm{N}\right)$ to $-0.58(P=0.0001)$ at the southern end (Lamesa station, $32.72^{\circ} \mathrm{N}$ ) (Fig. 5). There was no correlation between the two variables at the Hereford station. Overall, there was an inverse relationship between latitudinal positions and the degree of correlation between cumulative daily maximum temperature departure from $30^{\circ} \mathrm{C}$ and cumulative precipitation $\left(r^{2}=0.71, P=0.0222\right)$ (Fig. 5) for stations that had significant correlations, indicating that the southern end of the Panhandle may depend more on precipitation for achievement of an ergot-favorable temperature range than the northern Panhandle.

Cross-spectral analysis. Weather data from the two stations in the northern section (Dalhart and Dumas) showed weak relationships overall with the prevalence of ergot; therefore, time series analysis was conducted only on data from the five stations in the southern section. Tests of the weather data for white noise showed that both series from all five stations were suitable for time series analysis ( $\alpha \leq 0.05$ for four of the stations, and $\alpha=0.1$ for one of the stations). The cospectra for all five stations showed that the temperature and precipitation series were negatively associated during the periodic cycles. However, at some of the stations, there were little or no associations at certain periodic cycles. For

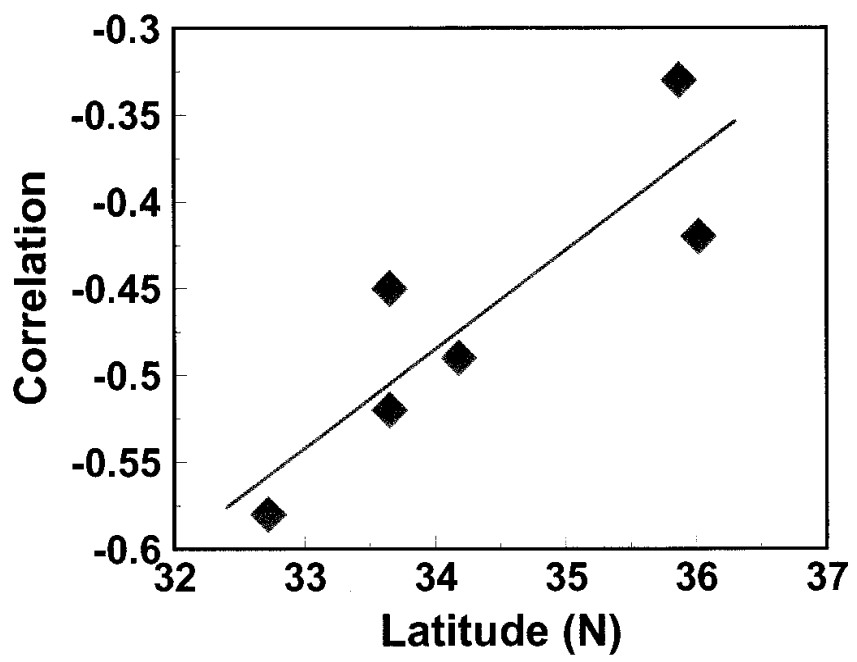

Fig. 5. Relationship between latitudinal positions and degree of correlation between depression in maximum temperature and cumulative precipitation $\left(R^{2}=0.71, P=0.0222, Y=-2.42+0.057 X\right)$ for six locations in the Texas Panhandle. example at the Lamesa and Plainview stations, the cospectrum was near zero at periodicities of 4.2 to 5 years (Fig. 6A and B), indicating periods in which there was little or no effect of precipitation on maximum temperature.

Unlike the cospectrum, coherence is a measure of correlation that takes both the negative and positive association of two series into account (23). As in ordinary correlation coefficients, coherence values vary between 0 and 1 ; values close to 1 indicate strong association and those close to 0 signal weak association. Cross-spectral analysis results from all five stations showed coherency values that ranged between 0.52 and 0.83 , signaling the existence of fair to strong association between temperature and precipitation during the periodic cycles. The coherency values were significant $(\alpha<0.05)$ at periodicities that ranged between 2.2 and 4.0 years (Fig. 7A to E). The three stations at the southern end of the Panhandle, Crosbyton, Lamesa, and Lubbock (Fig. 7A, $\mathrm{C}$, and $\mathrm{D}$, respectively) showed additional coherency peaks of 6.25 to $8.3,7.1$ to 16.7 , and 7 to 10 years, respectively.

\section{DISCUSSION}

Sorghum ergot is a destructive disease that can cause yield loss of up to $80 \%$ (4). In 1997, many people were surprised by the rapid spread of the disease across what is normally a hot and dry region of Texas. Equally surprising was the sudden decline of the disease during the subsequent 3 years. The present investigation was initiated to determine whether climatic factors were associated with variations in disease events during the past 4 years. The study showed that variations in the prevalence of the disease were strongly associated with temperature and precipitation.

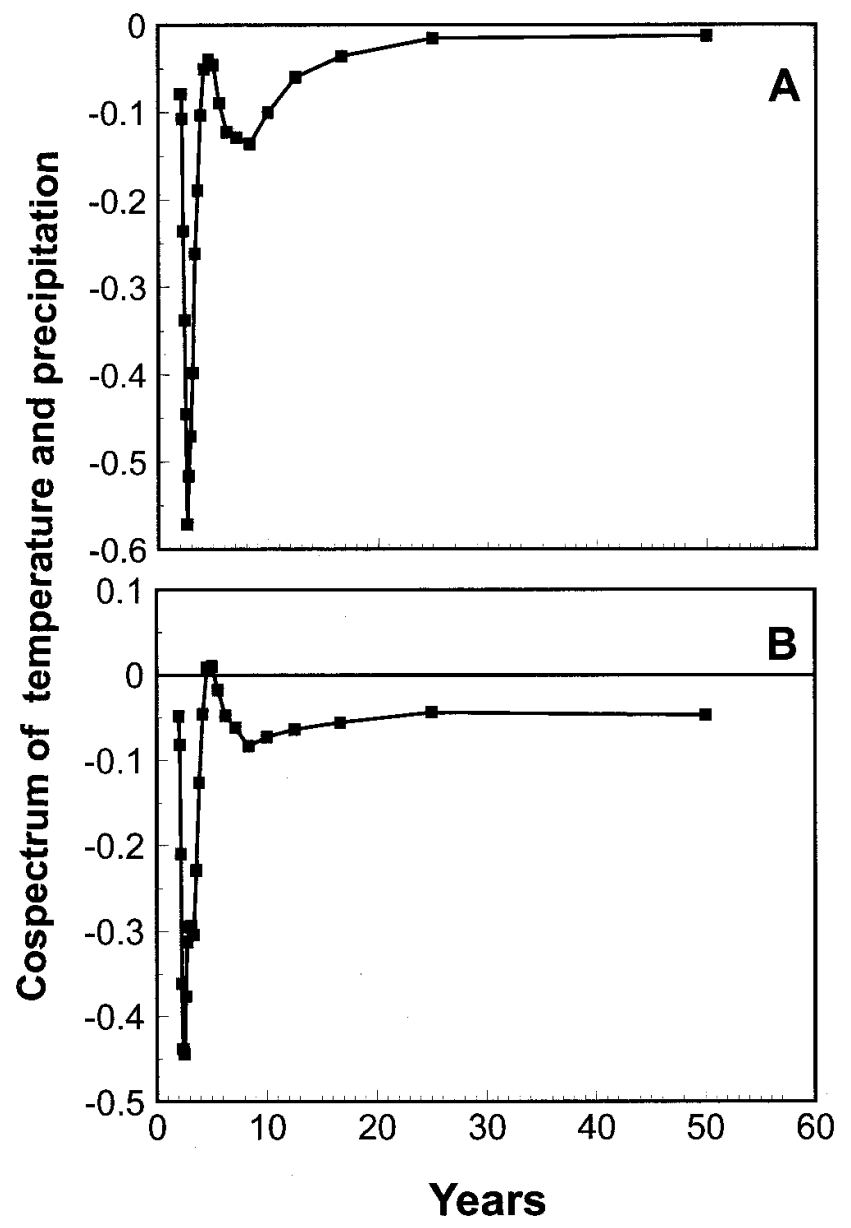

Fig. 6. Cospectrum of cumulative maximum temperature departure and cumulative precipitation for $\mathbf{A}$, Lamesa and $\mathbf{B}$, Plainview stations during 1 to 15 August from 1950 to 2000. 
The year 1997 was cooler and wetter than each of the other 3 years during peak flowering, and the prevalence of ergot was the greatest that year. This is in agreement with published reports that development of sorghum ergot is favored by cool climatic conditions with near $100 \%$ relative humidity (20). McLaren and Flett (29) reported that mean daily maximum temperature during anthesis was one of the climatic variables that strongly influenced sorghum ergot severity. In addition, the development of ergot is reported to be negligible at temperatures $\geq 28$ to $30^{\circ} \mathrm{C}(4,30)$. In the present study, use of cumulative departures of maximum temperature from the base line of $30^{\circ} \mathrm{C}$ and cumulative precipitation enabled us to successfully relate precipitation and temperature to the prevalence of the disease. The approach clearly distinguished between years with differing disease prevalence, temperature, and precipitation.

In the southern section of the Panhandle, there was a strong relationship between the weather variables and the prevalence of ergot during the first half of August. However, in the northern section, only temperature had a significant relationship with ergot prevalence. In addition, the observed relationship was during the period of 16 to 31 July, not 1 to 15 August. The differences between the two sections may be related to the fact that the northern section is generally cooler than the southern section and the weather may be favorable to ergot as early as the last half of July. However, the disease was not as widely spread as in the southern section for unknown reasons.

Infection of sorghum flowers by $C$. africana and subsequent disease development is reported not to require free moisture as long as the relative humidity is greater than $90 \%$ (20). However, in the Texas Panhandle, high relative humidity rarely exists in the absence of rainstorms or scattered showers. In this investigation, precipitation accounted for $99 \%$ of the variations in relative humidity in both the north and south sections of the Texas Panhandle. Precipitation may also have a moderating effect on what otherwise is an ergot-hostile summer climate in the region. It is generally understood that, in arid environments, rain events often are accompanied by temperature depression, to a certain degree, due to evaporative cooling. In 1997, rain events were associated

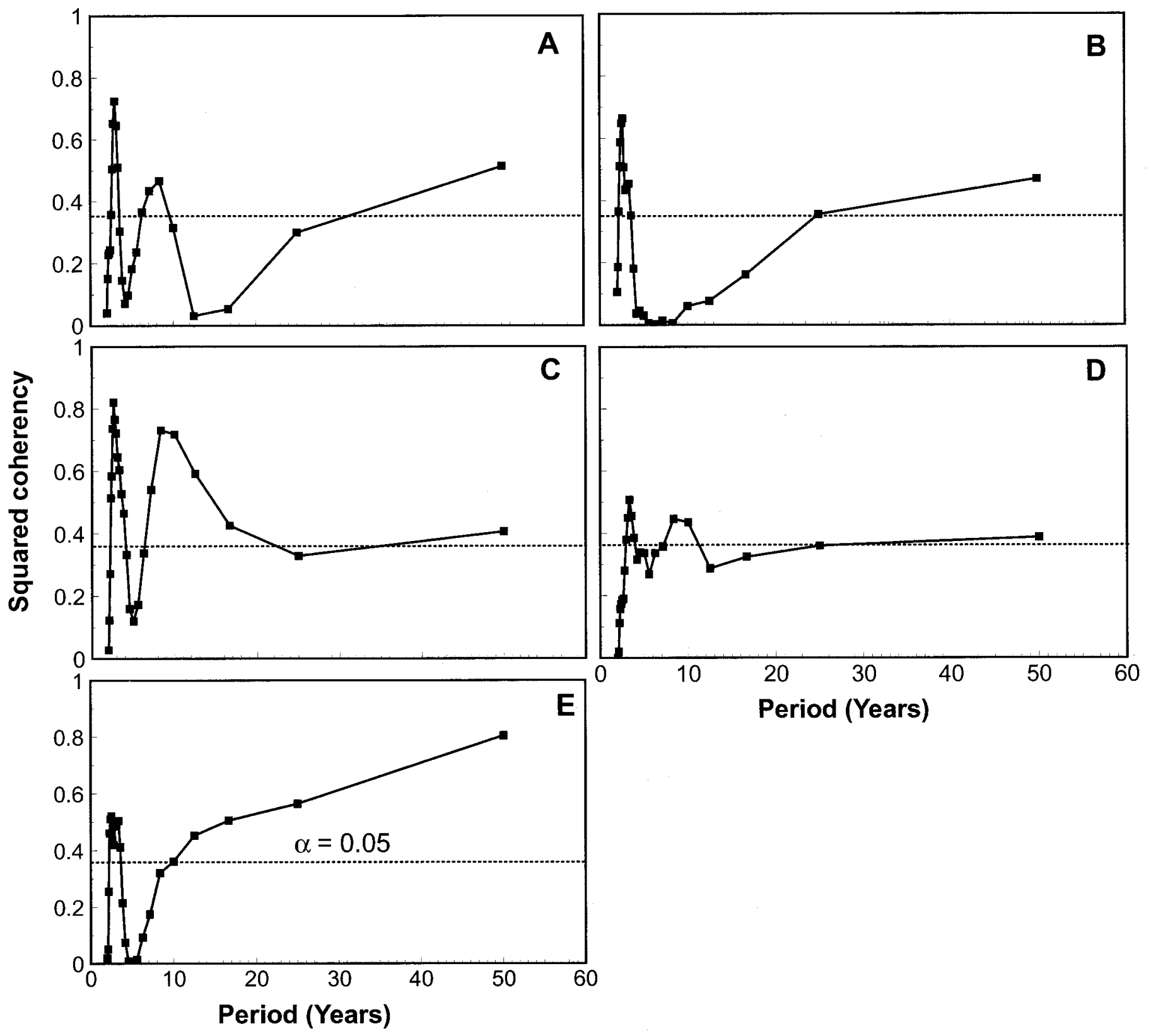

Fig. 7. Coherence of cumulative maximum temperature departure (from the base line of $30^{\circ} \mathrm{C}$ ) and cumulative precipitation during 1 to 15 August for $\mathbf{A}$, Crosbyton, B, Hereford, C, Lamesa, D, Lubbock, and E, Plainview stations from 1950 to 2000. 
with the occurrence of cool weather conditions that favored ergot development. The fact that there were many instances during the last 50 years in which temperature depression was associated with rain events show that the 1997 weather pattern was not unique. The strength of the association between the two increased with decreasing latitudinal locations. This is expected because the northern end of the Panhandle normally tends to be cooler than the southern end during the summer and, therefore, precipitation may not be as critical for enhancing the occurrence of cool climatic conditions that favor ergot development.

We used cross-spectral analyses to assess whether such climatic conditions have periodic patterns. Cross-spectral analysis is a statistical tool that is used to determine periodic patterns of time- or space-related observations, and has been employed successfully in plant pathology and several other disciplines $(6,14,26,32,34,36)$. The analysis indicated that association of precipitation and temperature depression has periodic patterns and there were some variations between weather stations. Three of the stations in the southern end had additional coherency of 7 years or greater, in addition to the 2- to 4-year periodicity common to all the stations. Both the cospectrum and coherence showed that, in some of the locations, there was little or no association between cumulative maximum temperature and cumulative precipitation at certain periodicities. This may be due to the fact that sometimes rain events in the Panhandle occur late in the evening or at night, after temperature had declined from its daily maximum. In such occasions, there would much less effect of precipitation on maximum temperature.

This study demonstrated that weather factors were associated with variations in prevalence of ergot in the Texas Panhandle during the last 4 years, and that maximum temperature and precipitation were significantly associated with the variations. Even though precipitation by itself related less strongly to ergot prevalence than temperature, its major effect, in addition to providing humid conditions, may be indirect by suppression of maximum temperature. This suggests that, in light of the normally dry and hot climatic conditions, precipitation may be the primary prerequisite for incidence of ergot in the region. However, the role irrigation plays in development of ergot-conducive conditions in specific fields is unknown. In 1999, of the 1.4 million acres of sorghum planted in the Panhandle, approximately $34 \%$ were irrigated (1) and essentially all seed production fields are irrigated. The effect of irrigation on inducing ergot-favorable microclimate around the sorghum flowers, especially during the night, needs further investigation.

Minimum temperatures below $12^{\circ} \mathrm{C}$ affect pollen viability, reducing fertilization efficiency and consequently exposing the ovaries to infection by $C$. africana $(8,12)$. In South Africa, 5 consecutive days of minimum temperature below $12^{\circ} \mathrm{C} 3$ weeks before anthesis was one of the primary factors that significantly contributed to the severity of sorghum ergot (31). In the Texas Panhandle, however, such conditions rarely occur prior to or during flowering periods; therefore, minimum temperature is less of a factor than maximum temperature in development of sorghum ergot in the region.

We have attempted to determine the relationships between weather factors and the prevalence of ergot in the Texas Panhandle during the last 4 years, using ergot prevalence data collected from the seed companies in the region. The study answered, in part, the question of factors associated with the disease epidemic of 1997 and its subsequent decline. Results showed that association of temperature and precipitation is a primary factor in development of ergot, and such association is periodic. However, the source of inoculum in the Texas Panhandle still is not clear. The pathogen is known to survive as sclerotia and on several collateral hosts, including wild sorghum relatives (20). In the Texas Panhandle, this has not yet been proven to be the case. It is speculated that the pathogen survives on wild perennial hosts in Mexico and Southern Texas, and spores are blown northward in the spring and summer. However, Jensen (24) showed that the spores are able to survive the winter in North America on infected heads in sorghum fields. The widespread epidemic of 1997 may have been the result of massive spores being blown north with rainstorms from the Gulf. However, the sporadic nature of the disease in the Texas Panhandle during the last 3 years supports the view that the pathogen, in one form or another, may survive the winter in sorghum fields. The periodic cycles described in this article stress only the meteorological aspects of the disease epidemiology and do not include aspects of inoculum availability during the periodic cycles of conducive climate. The probability of recurrence of another epidemic depends in part on inoculum availability and dispersal. Weather patterns may be conducive during periodic cycles but may not necessarily be associated with an ergot epidemic as in 1997. The source of inoculum and spore release and dispersal patterns still remain to be identified.

\section{ACKNOWLEDGMENTS}

We thank the various seed companies in the Texas Panhandle who provided us with field information on ergot prevalence and sorghum flowering dates. This project was supported in part by grants from Texas research initiatives, TxGrain, and Precision Agriculture.

\section{LITERATURE CITED}

1. Anonymous. 1999. Texas Agricultural Statistics. Texas Agric. Stat. Serv. Bull. 258, Texas Department of Agriculture, Austin.

2. Anonymous. 2002. National Agricultural Statistical Service, U.S. Dep. Agric. Crop values: 2001 summary.

3. Arias-Rivas, B., Silva, F., and Cabrera, N. 1997. Sugary disease or ergot in sorghum seed fields on the Guanipa Plateau, Anzoategui State, Venezuela. Int. Sorghum Millets Newsl. 38:64-65.

4. Bandyopadhyay, R., Frederickson, D. E., McLaren, N. W., Odvody, G. N., and Ryley, M. J. 1998. Ergot: A new disease threat to sorghum in the Americas and Australia. Plant Dis. 82:356-367.

5. Bartlett, M. S. 1966. An Introduction to Stochastic Processes with Special Application to Methods and Applications. Cambridge University Press, Cambridge.

6. Bourodimos, E. L., and Oguntuase, A. M. 1973. Cross-spectral analysis of rainfall and runoff for Raritan and Mullica River basins in New Jersey. J. Hydrol. 21:61-79.

7. Box, G. E., and Cox, D. R. 1964. An analysis of transformations. J. Roy. Stat. Soc. 26:211-252.

8. Brooking, I. R. 1976. Male sterility in sorghum bicolor (L) Moench induced by low night temperature. I. Timing of the stage of sensitivity. Aust. J. Plant Physiol. 3:589-596.

9. Brown, D., and Rothery, B. 1993. Models in Biology: Mathematics, Statistics and Computing. John Wiley \& Sons, New York.

10. Davis, J. C. 1986. Statistics and Data Analysis in Geology. 2nd ed. John Wiley, New York.

11. Dean, D. W., Jones, C. L., Hines, R. H., Hancock, J. D., Porter, J. K., and Russell, R. B. 2001. Effects of sorghum ergot in diets for broiler chicks. Page 58 in: Proc. Biennial Grain Sorghum Res. Conf, 22nd. Lubbock, TX.

12. Downs, R. W., and Marshall, D. R. 1971. Low temperature induced male sterility in sorghum bicolor. Aust. J. Exp. Agric. Anim. Husb. 11:352356

13. Durbin, J. 1967. Tests of serial independence based on the cumulated periodogram. Bull. Int. Stat. Inst. 42:1039-1049.

14. Folorunso, O. A., and Ralston, D. E. 1985. Spatial and spectral relationships between field-measured denitrification gas fluxes and soil properties. Soil Sci. Soc. Am. J. 49:1087-1093.

15. Frederickson, D. E., and Mantle, G. E. 1988. The path of infection of sorghum by Claviceps sorghi. Physiol. Mol. Plant Pathol. 33:221-234.

16. Frederickson, D. E., Mantle, P. G., and de Milliano, W. A. J. 1989. Secondary conidiation of Sphacelia sorghi on sorghum, a novel factor in the epidemiology of ergot disease. Mycol. Res. 93:497-502.

17. Frederickson, D. E., Mantle, P. G., and de Milliano, W. A. J. 1993. Windborne spread of ergot disease (Claviceps africana) in sorghum A-lines in Zimbabwe. Plant Pathol. 42:368-377.

18. Fuller, W. A. 1976. Introduction to Statistical Time Series. John Wiley \& Sons, New York.

19. Futrell, M. C., and Webster, O. J. 1965. Ergot infection and sterility in grain sorghum. Plant Dis. Rep. 49:680-683.

20. Futrell, M. C., and Webster, O. J. 1966. Host range and epidemiology of 
the sorghum ergot organism. Plant Dis. Rep. 50:828-831.

21. Isakeit, T., Odvody, G. N., and Shelby, R. A. 1998. First report of sorghum ergot caused by Claviceps africana in the United States. Plant Dis. 82:592.

22. Jenkins, G. M. 1961. General considerations in the analysis of spectra. Technometrics 3:133-166.

23. Jenkins, G. M., and Watts, D. G. 1968. Spectral Analysis and its Applications. Holden-Day, San Francisco.

24. Jensen, S. G. 1998. Winter survival of Claviceps africana in the Central Plains of the USA. Int. Sorghum Millets Newsl. 39:113-114.

25. Koopmans, L. H. 1995. The Spectral Analysis of Time Series. Academic Press, New York.

26. Krupa, S. V., and Nosal, M. 1989. Application of spectral coherence analysis to describe the relationships between ambient ozone exposure and crop growth. Environ. Pollut. 60:319-330.

27. McLaren, N. W. 1993. Effect of sugary disease exudates on germination, seedling development and predisposition to seedling diseases of sorghum (Sorghum bicolor). S. Afr. J. Plant Soil 10:12-16.

28. McLaren, N. W. 1997. Changes in pollen viability and concomitant increase in incidence of ergot of sorghum ergot with flowering date and implications in selection for escape resistance. J. Phytopathol. 145:261265.

29. McLaren, N. W., and Flett, B. C. 1998. Use of weather variables to quantify sorghum ergot potential in South Africa. Plant Dis. 82:26-29.
30. McLaren, N. W., and Wehner, F. C. 1990. Relationship between climatic variables during early flowering of sorghum and the incidence of sugary disease caused by Sphacelia sorghi. J. Phytopathol. 130:82-88.

31. McLaren, N. W., and Wehner, F. C. 1992. Pre-flowering low temperature predisposition of sorghum to sugary disease (Claviceps africana). J. Phytopathol. 135:328-334.

32. Molenat, J., Davey, P., Gascuel-Odoux, C., and Durand, P. 1999. Study of three subsurface hydrologic systems based on spectral and cross-spectral analysis of time series. J. Hydrol. 222:152-164.

33. Owen, D. B. 1962. Handbook of Statistical Tables. Addison-Wesley, Palo Alto, CA

34. Plat, T., and Denman, K. L. 1975. Spectral analysis in ecology. Annu. Rev. Ecol. Syst. 6:189-210.

35. Reis, E. M., Mantle, P. G., and Hassan, H. A.-G. 1996. First report in the Americas of sorghum ergot disease, caused by a pathogen diagnosed as Claviceps africana. Plant Dis. 80:463.

36. Scherm, H., and Yang, X. B. 1995. Interannual variations in wheat rust development in China and the United States in relation to the El Nino/Southern Oscillation. Phytopathology 85:970-976.

37. Shumway, R. H., and Stoffer, D. S. 2000. Time Series Analysis and its Applications. Springer-Verlag, New York.

38. Velasquez-Valle, R., Narro-Sanchez, J., Mora-Nolasco, R., and Odvody, G. N. 1998. Spread of ergot of sorghum (Claviceps africana) in Central Mexico. Plant Dis. 82:447.

\section{Erratum}

Vol. 92, No. 6, 2002

In the manuscript entitled "Evaluation of Relationships Between Weather Patterns and Prevalence of Sorghum Ergot in the Texas Panhandle" by F. Workneh and C. M. Rush (Phytopathology 92:659-666), the authors thank the various seed companies in the Texas Panhandle who provided field information on ergot prevalence and sorghum flowering dates. The project was supported in part by grants from Texas Research Initiatives, TxGrain, Texas Higher Education Coordinating Board, and Precision Agriculture. The authors also thank N. W. McLaren for valuable comments and suggestions. 